\title{
15. İngilizce dersi akademik performansını etkileyen bireysel faktörler
}

Özge CAN ARAN 1

\section{Nazlı Demet YILMAZ²}

APA: Can Aran, Ö.; Yılmaz, N. D. (2021) İngilizce dersi akademik performansını etkileyen bireysel faktörler. RumeliDE Dil ve Edebiyat Araştırmaları Dergisi, (22), 280-289. DOI: 10.2900o/rumelide.895790.

\section{$\ddot{O} \mathbf{z}$}

$\mathrm{Bu}$ araştırma, öğrencilerin İngilizce dersi akademik performanslarını etkileyen bireysel faktörleri kuramsal olarak incelemeyi amaçlamaktadır. Öğrencilerin İngilizce dersi akademik performanslarını etkileyen olumlu ve olumsuz faktörlerin ortaya çıkarılmasının, öğrenen özelliklerinin daha iyi tanımlanmasında ve etkili öğrenme ortamlarının düzenlenmesinde faydalı olacağı düşünülmektedir. Bu kapsamda araştırmada başarı ve başarısızlığa yapılan yüklemeler, akademik öz yeterlik algısı, yabancı dil kaygısı ve dil öğrenme stratejileri bireysel faktörler olarak ele alınmıştır. Öğrencilerin İngilizce dersi akademik performanslarına etki eden faktörlerin kuramsal olarak tartışıldığı bu araştırmanın, etkili yabancı dil öğrenme ortamlarının düzenlenmesinde, hem program geliştiricilere hem de program uygulayıcılarına rehberlik edeceği düşünülmektedir. Araştırma sonuçlarına dayalı olarak düzenlenen öğrenme ortamlarının öğrenenlerin öğrenme davranışlarının farkında olması ve dil öğrenimi konusunda olumlu tutum geliştirmesine de katkı getirmesi hedeflenmektedir.

Anahtar kelimeler: Yabancı dil öğretimi, İngilizce dersi, bireysel faktörler

\section{Individual factors influencing academic performance in English language course}

\begin{abstract}
This research aims to theoretically examine the individual factors that affect students' academic performance in English course. It is thought that revealing the positive and negative factors that affect the academic performance of students in English course will be beneficial in defining the learner characteristics better and in organizing effective learning environments. In this context, attributions to success and failure, academic self-efficacy perception, foreign language anxiety and language learning strategies were considered as individual factors. This study, in which the factors affecting students' academic performance in English course are discussed theoretically, is thought to be a guide for both program developers and program practitioners in organizing effective foreign language learning environments. It is aimed that the learning environments organized based on the results of this research will contribute to the awareness of learners' about their own learning behaviors and to the development of a positive attitude towards language learning.
\end{abstract}

Keywords: Foreign language teaching, English course, individual factors

Dr. Öğr. Üyesi, Hacettepe Üniversitesi, Eğitim Fakültesi, Eğitim Bilimleri Bölümü, Eğitim Programları ve Öğretim ABD (Ankara, Türkiye), ozgecanno6@gmail.com, ORCID ID: oooo-0003-3229-4325 [Araştırma makalesi, Makale kayıt tarihi: 10.02.2021-kabul tarihi: 20.03.2021; DOI: 10.29000/rumelide.895790]

MEB, Şehit Hüseyin Mertoğlu İmam Hatip Ortaokulu (Burdur,Türkiye), nazlidemetyilmaz@gmail.com, ORCID ID: oooo-0002-2756-5613

RumeliDE Dil ve Edebiyat Araşttrmaları Dergisi Osmanağa Mahallesi, Mürver Çiçeği Sokak, No:14/8 Kadıköy - ISTANBUL / TÜRKIYE 34714 e-posta: editor@rumelide.com tel: +90 $5057958124,+902167730616$
Address

RumeliDE Journal of Language and Literature Studies

Osmanağa Mahallesi, Mürver Çiçeği Sokak, No:14/8

Kadıköy - ISTANBUL / TURKEY 34714

e-mail: editor@rumelide.com,

phone: +90 5057958124, +90 2167730616 


\section{Giriş}

Toplumlar arasındaki iletişim sürecinin giderek daha da fazla önem kazanması ve iletişim kanallarının hızla çoğalması sonucunda yabancı dil bilmek bireyin sahip olması gereken en önemli niteliklerden biri haline gelmiştir (Baran ve Halıcı, 2006; Oğuz ve Baysal, 2015). Dünya üzerinde birçok dil olmakla birlikte, bir dilin farklı uluslar tarafından öğrenilmesindeki ölçüt o dili konuşan ülkenin politik ve ekonomik durumudur (Demirel, 2020). Bu noktada İngilizcenin önemli bir dil olduğunu söylemek mümkündür. Önemi bilinmesine rağmen bir yabancı dili öğrenmek, pek çok birey için zor bir süreç olarak algılanmaktadır (Baş, 2014a). Yabancı dil öğrenme sürecini birçok faktörün etkilediğini söylemek mümkündür. Örneğin ortaokul öğrencileri dil öğrenirken çok yüksek düzeyde yaşadıkları zorlukları sırasıyla öğretimin niteliği, öğrenme iklimi, öğrenme kaynakları ve öğrenenden kaynaklanan zorluklar olarak belirtirken, lise öğrencileri ise dil öğrenme sürecinde yaşadıkları zorlukları öğrenme kaynakları, öğrenenden (kendilerinden), öğretimin niteliği ve öğrenme ikliminden kaynaklanan zorluklar şeklinde sıralamıştır (Özmat, 2017). Aynı zamanda araştırma sonuçları, İngilizce öğrenme konusunda öğrencilerin kendilerini yetersiz hissettikleri ve İngilizcenin öğrencilerin ilgilerini çekmediğini de (Besimoğlu, Serdar ve Yavuz, 2010; Özmat, 2017) göstermektedir. Bu noktada yabancı dil öğrenme sürecini bireyin eksik veya hatalı ön öğrenmeleri (Özmat,2017) gibi bilişsel etmenlerin yanı sıra duyuşsal faktörlerin de (Baş, 2014a; Özmat, 2017) önemli ölçüde etkilediğini söylemek mümkündür. Öğrencilere yabancı dil becerisini etkili şekilde kazandırmak için, öğrenci niteliğinin öğrenmelerin büyük bir kısmını açıkladığı (Bloom, 2012; Özçelik, 2013) göz önünde bulundurulmalıdır. Bialystok (1978) dil öğrenme yeteneği ve tutumu gibi bireysel öğrenen özelliklerinin, bir birey için dil öğrenme sürecinin verimliliğini ve aynı zamanda öğrenme stratejilerini ne ölçüde kullanacağını etkilediğini belirtmiştir. Araştırmalar aynı zamanda dil öğretiminin başarıya ulaşmasını engelleyen etmenlerin başında olumsuz tutum (Perez, 1995; Şad, 2011), düşük motivasyon (Li, 2016; Perez, 1995; Şad, 2011) ve yüksek kaygının (Şad, 2011) geldiğini göstermektedir. Aydemir' in (2007) araştırması ise düşük motivasyonun en önemli kaynaklarından birisinin öğrencilerin başarı ya da başarısızlıklarına yaptıkları yüklemeler olduğunu ortaya koymuştur. Bu noktada öğrencilerin başarı ya da başarısızlıklarına yaptıkları yüklemelerin araştırılmasının, öğrencilerin İngilizce öğrenmeye yönelik olumsuz duyuşsal özelliklerinin kaynağının ortaya çıkarılması açısından önemli olduğunu söylemek mümkündür. Çünkü başarısızlıklarını İngilizce öğrenme yetenekleri olmaması ve İngilizce derslerindeki görevlerin zorluğuna bağlayan öğrenciler, İngilizceyi zor bir dil olarak görmektedir (Semiz,2011). Bu kapsamda bu araştırmada öğrencilerin İngilizce öğrenmelerini etkilediği düşünülen ve araştırmacılar tarafindan öncelikli olarak araştırılan bireysel faktörlere ilişkin bulgular ortaya konmuş ve bu bulgulardan yola çıkarak yabancı dil öğrenme başarısını arttırmaya yönelik önerilerde bulunulmuştur.

\section{Yabancı dil öğrenmeyi etkileyen bireysel faktörler}

Öğrenmeyi potansiyel olarak davranıştaki değişme; performansı ise, bu potansiyelin davranışa dönüştürülmesi olarak tanımlamak mümkündür (Senemoğlu,2013). Öğrenme süreci bireylerin farklılıklarına göre şekil alan bir süreçtir. Kalıcı izli davranış değişikliğinin oluşmasında yani öğrenmenin meydana gelmesinde, farklı birçok değişken, her birey için öğrenme sürecinin farklılaşmasına sebep olur (Akpur,2005). Öğrenmenin hangi koşullar altında oluşacağı ya da oluşmayacağını öğrenme kuramları açıklamaktadır. Öğrenme temelde davranışçı ve bilişsel öğrenme kuramları ile açıklanabilir (Senemoğlu, 2013). Davranışçı öğrenme kuramları, öğrenmede zihinsel faktörleri reddetmemekle birlikte bu faktörlerin öğrenme sürecinde önemli bir fonksiyona sahip olmadıklarını savunur ve öğrenmeyi uyarıcı ile tepki arasında bağ kurma işi olarak açıklar (Erden ve

\begin{tabular}{r|l} 
Adres & Address \\
RumeliDE Dil ve Edebiyat Arasturmalart Dergisi & RumeliDE
\end{tabular} Osmanağa Mahallesi, Mürver Çiçeği Sokak, No:14/8 Osmanağa Mahallesi, Mürver Çiçeği Sokak, No:14/8

Kadıköy - İSTANBUL / TÜRKIYE 34714 Kadıköy - ISTANBUL / TURKEY 34714 e-posta: editor@rumelide.com tel: +90 505 7958124, +90 2167730616 phone: +90 505 7958124, +90 2167730616 
Akman, 2014). Bilişsel öğrenme kuramları ise, gözlenebilen davranışlara ek olarak, öğrenenin zihninde olup bitenlerle, içsel yapılarla ilgilenir ve öğrenenlerin zihinsel süreçlerinin özelliklerini, fonksiyonları belirleyen ilkeleri, yasaları ortaya koymaya çalışmaktadır (Senemoğlu, 2013). İnsan zihninin dünyayı ve çevresindeki olayları anlamaya yönelik yaptığı işlerin tümü olarak betimlenen biliş kavramı, bireyin bilgiye ulaşma sürecini açıklamaya çalışan ve zihinsel yapılarındaki değişmeyi bilişsel öğrenme şeklinde ifade eden bilişsel öğrenme kuramlarının temelini özetlemektedir (Akpur, 2005). Bilişsel öğrenme kuramları, öğrenmeyi gözlenebilir davranışların ötesinde gözlenemeyen bilişsel süreçlerle açıklamaya çalışmaktadır (Altun ve Çolak, 2011). Bilişsel öğrenme kuramlarının, öğrenmede zihinsel süreçlerin önemine yaptığı vurgu, her bir öğrenme sürecinin bireyden bireye değişen, bireyin farklılıklarına göre şekil alan bir süreç haline gelmesine sebep olmuştur (Akpur, 2005). Bireylerin İngilizce dersi akademik performanslarını etkileyen bireysel faktörlerin betimlenmesi, öğrenen özelliklerinin daha iyi tanımlanması ve böylece öğretim hizmetinin öğrenenleri merkeze alarak düzenlenmesi hususunda uygulayıcılara rehberlik eder. Bloom (2012), olumlu öğrenme koşulları sağlandığında, dünyada herhangi bir kişinin öğrendiği işi hemen hemen herkesin öğrenebileceğini ifade etmiştir. Bu noktada öğrencilerin İngilizce öğrenmelerini etkilediği düşünülen ve alanyazında sık karşılaşlan faktörlerin incelenmesinin önemli olduğu düşünülmektedir. Bu araştırmada öğrencilerin İngilizce dersinde akademik performanslarını etkileyen bireysel faktörler, onların başarı ve başarısızlıklarına yaptıkları yüklemeler (Nolen-Haoksema, Girgus, Seligman,1986; Ritchie, 1999), akademik öz yeterlik algıları (Özmat, 2017; Shih, 2019), yabancı dil kaygıları (Akpur, 2005; Çimen, 2011; Özmat, 2017; Shih, 2019), dil öğrenme stratejileri (Demirel, 2012; Özmat, 2017; Perez, 1995; Shih, 2019) başlıkları altında incelenmiştir.

\section{Başarı ve başarısızlığa yapılan yüklemeler}

Öğrencilerin başarı ve başarısızlıklarına yaptıkları yüklemelerin başarılarını etkilediği belirtilmektedir (Weiner,1986). Başarı ve başarısızlığa yapılan yükleme teorileri kapsamında Weiner' ın Yükleme Teorisi önemli teorilerden birisidir. Weiner, bireyleri başarıya ve başarısızlığa götüren davranışlarda bulunmalarının temel sebebinin onların başarı veya başarısızlıklarına ilişkin inançları olduğunu ileri sürmüştür. Weiner'ın yükleme teorisine göre bireylerin başarı ve başarısızlı̆̆na yönelik inançları, başarılması gereken işe yönelik algısı ile gösterdiği davranış arasında aracı bir role sahiptir. Bu teoriye göre, bireyler başarı veya başarısızlığını yetenek, çaba, şans ve görevin zorluğu gibi dört sebepten birine atfetmektedir. Bireylerin başarılarını içsel nedenlere atfetmesi (yetenek ve çaba) çalışma ve başarı getirirken, başarısızlıklarını dışsal nedenlere (şans ve görevin zorluğu) atfetmesi ise, vazgeçmeyi ve başarısızlığı getirmektedir (Güloğlu, 2015). Yabancı dil öğrenen başarılı öğrencilerin, başarısız öğrencilere kıyasla daha çok içsel ve kişisel yüklemelerde bulundukları görülmüştür. Ayrıca yükleme inançları, öz-yeterlik ve dil öğrenme inanışları arasında önemli ilişkilerin bulunduğu da belirtilmektedir (Semiz, 2011).

Öğrencilerin başarı beklentisi, olumsuz inanışları nedeniyle azalmaktadır. Bu kapsamda öğrencilerin öğrenilmiş çaresizliklerinin başarılarını etkilediği belirtilmektedir (Weiner,1986). Çünkü organizma ne kadar çaba gösterirse göstersin durumu değiştiremeyeceğini anladığında pasif kalmakta ve bunu diğer durumlara da genellemektedir (Senemoğlu, 2013). Araştırmacılar, insanların kontrol etme imkânlarının güç olduğu, öğrenilmiş çaresizlik geliştirdikleri durumlarda gösterdikleri farklı tepkileri araştırmaya başlayarak, bireylere özgü açıklama tarzlarının neler olduğuna dair birçok araştırma yapmaya başlamıştır (Ritchie, 1999). Açılama tarzı, bireylerin olayların olma nedenlerini kendilerine açıklarken kullanmayı alışkanlık haline getirdiği tarzdır (Seligman, 2007). Bazı bireyler başlarına gelen kötü olayları ve başarısızlıkları açıklarken kendilerine içsel yüklemeler yaparlarken, bazı bireyler de

RumeliDE Dil ve Edebiyat Araştırmaları Dergisi Osmanağa Mahallesi, Mürver Çiçeği Sokak, No:14/8 Kadıköy - ÍSTANBUL / TÜRKIYE 34714 e-posta: editor@rumelide.com tel: +90 505 7958124, +90 2167730616
Address

RumeliDE Journal of Language and Literature Studies

Osmanağa Mahallesi, Mürver Çiçeği Sokak, No:14/8

Kadıköy - ISTANBUL / TURKEY 34714

e-mail: editor@rumelide.com,

phone: +90 $5057958124,+902167730616$ 
başlarına gelen kötü olayların, şanssızlıkların nedenlerini dış koşullarda aramaktadırlar (Richie, 1999). Bireylerin kötümser ya da iyimser açıklama tarzları öğrenilmiş çaresizlik geliştirmelerinde etkili olmaktadır. İyimser bir açılama tarzı, çaresizliğe son verirken, kötümser bir açılama tarzı öğrenilmiş çaresizliği yaygınlaştırır ve derinleştirir (Seligman, 2007). Öğrenilmiş çaresizlik kuramına göre, olumsuz olaylara kalıcı ve yaygın yüklemeler yapan bireyler, gelecekte başlarına gelecek olayların kontrol edilemez olduğuna inanırlar ve çaresizlik geliştirmeye daha fazla yatkın olurlar. Olumsuz olaylara geçici yüklemeler yapanlar ise, başlarına gelecek olumsuz olaylar üzerinde daha fazla kontrol sahibi olduklarına inanırlar (Gillham, Shatte, Reivich, Seligman, 2001). Yapılan bir araştırma sonucunda okul çağındaki öğrencilerden yaşamlarındaki olumsuz olaylara kişisel, kalıcı ve yaygın yüklemeler yapanlar ve yaşamlarındaki olumlu olaylara dışsal, geçici ve bir olaya özgü yüklemeler yapanlar akademik performanslarında daha fazla sorun yaşamışlar ve daha fazla depresyon belirtileri göstermişlerdir (Nolen-Haoksema, Girgus, Seligman, 1986). Ritchie (1999) de araştırmasında öğrencilerin açıklama tarzları ve akademik performansları arasındaki ilişkiyi incelemeyi ve üniversite öğrencilerinin akademik performanslarını yordamada olaylara yaptıkları açılama tarzlarının etkili olup olmadığını belirlemeyi amaçlamıştır. Araştırma sonuçlarına göre akademik yükleme stillerinin başarıyı yordamada etkili olduğu görülmüştür. Taşkıran ve Aydın’ın (2017) yaptıkları araştırma sonuçlarına göre öğrenciler İngilizce dersinde başarıya kıyasla başarısızlık algısı üzerine daha fazla nedensel yükleme yapmışlardır. Besimoğlu, Serdar ve Yavuz' un (2010) araştırmasının sonuçları öğrencilerin başarı ve başarısızlıklarına yaptıkları yükleme olarak sırasıyla en fazla strateji kullanımı, ilgi ve çaba göstermeyi belirttiklerini göstermektedir. Aydemir' in (2007) ortaokul öğrencileri ile yaptığı araştırmasında ise, öğrenme stratejilerini kullanarak kendi öğrenmelerini düzenleyen öğrencilerin başarı gösterdikleri ve başarılı öğrencilerin başarılarında hem içsel hem de dışsal yüklemeleri daha fazla yaparken, başarısızlıklarında daha az dışsal yükleme yapmakta oldukları görülmüş̧ür. Yüklemeler ve öğrenme stratejileri kullanımı arasında bir ilişkiye rastlanırken, yüklemelerin güdüyü; güdülenme derecesinin öğrenme isteğini; öğrenme isteğinin öğrenme stratejisi kullanım düzeyini etkilediği görülmüştür.

\section{Akademik öz-yeterlik}

Albert Bandura'ya göre öz yeterlik bireyin belli bir işi yapabilmek için, gerekli etkinlikleri organize edip başarıyla yapabilme kapasitesine ilişkin kendi yargısı olarak tanımlanmaktadır (Altun ve Çolak, 2011). Bireyin yeterlik inancı ve sosyal bir sistem içerisindeki performans göstergelerinin onun davranışlarını (Bandura,1997) belirlediği düşünüldüğünde, bireyin davranışlarını düzenlemede öz yeterliğin önemli bir role sahip olduğunu söylemek mümkündür. Öz yeterlik algısı yüksek olan bir birey, öz yeterlik algısı düşük olan bir bireye göre, bir işin üstesinden gelme konusunda kendisine daha çok güvenmektedir. Öz yeterlik, bireyin etkinliklerinin seçimini, bir etkinlikte harcayacağı çabayı, bir güçlükle karşılaştığında göstereceği sebat süresini, duyacağı kaygı ya da güven düzeyini etkiler (Senemoğlu, 2013). Alanyazında öğrencilerin öz-yeterlikleri ile İngilizce dersindeki performansları arasında pozitif bir ilişki olduğunu gösteren (Chen, 2020; Kitikanan ve Sasimonton, 2017; Weda, Abdul Samad, Patak ve Fitriani, 2018) araştırmalar yer almaktadır. Bu noktada öğrenciler yüksek özyeterliğe sahip olduklarında akademik performansları gelişecektir (Genç, Kuşaklı ve Aydın, 2013; Mahyuddin ve diğerleri, 2006). Öz-yeterliğin akademik başarıyı önemli derecede yordadığı da belirtilmektedir (Raoofi, Tan, BeeHoon ve Chan, 2012; Weiner,1986). Bu noktada öğrencilerin özyeterlik düzeylerini belirlemenin önemli olduğu düşünülmektedir. Gömleksiz ve Kılınç (2014) yaptıkları araştırma sonucunda lise öğrencilerinin İngilizce öz yeterlik inançlarının orta düzeyde olduğu sonucuna ulaşmıştır. Genç, Kuluşaklı ve Aydın (2013) ve Memduhoğlu ve Çelik'in (2015) araştırmaları sonucunda da, üniversite öğrencilerinin İngilizce öz yeterlik algılarının orta düzeye yakın

\begin{tabular}{r|l} 
Adres & Address \\
RumeliDE Dil ve Edebiyat Arastirmalar Dergisi & RumeliD
\end{tabular}

Osmanağa Mahallesi, Mürver Çiçeği Sokak, No:14/8 Osmanağa Mahallesi, Mürver Çiçeği Sokak, No:14/8

Kadıköy - ISTANBUL / TÜRKIYE 34714 Kadıköy - ISTANBUL / TURKEY 34714

e-posta: editor@rumelide.com e-mail: editor@rumelide.com,

tel: +90 505 7958124, +90 2167730616 phone: +90 505 7958124, +90 2167730616 
olduğu sonucuna ulaşılmıştır. Bunun yanı sıra, öğrencilerin olumsuz öz-yeterlik algılarının motivasyonu engellediği belirtilmektedir (Weiner,1986). Atitsogbui'nun (2014) çalışması, öz yeterliğin dışsal güdüleme değişkenlerinden çaba ve içsel güdüleme yapılarından ilgi ile ilişki içerisinde olduğunu da ortaya koymuştur. Alanyazında İngilizceye daha fazla zaman ayıran öğrencilerin İngilizce öz-yeterlik inançlarının yüksek çlktığı (Gömleksiz ve Kılınç, 2014) sonucuna ulaşan araştırmalara da rastlanmaktadır.

\section{Dil öğrenme stratejileri}

Öğrenme, öğretim sonucunda öğrencilerde oluşan gözlemlenemeyen durumlardan çok, bireyin karar verme yetkisi yoluyla kendisi için yaptığı bir aktivite olarak görülür (Zimmerman, 2002). Bu noktada öğrenme stratejileri, öğrencinin kendi kendine öğrenebilmesi için kullandığ işlemler olarak tanımlanabilir. Bu işlemler belleğe yerleştirme, geri getirme gibi bilişsel stratejilerin yanı sıra duyuşsal stratejiler ve yürütücü biliş süreçlerini de kapsamaktadır. Öğrencilerin uygun durumda uygun öğrenme stratejilerini kendilerinin seçip kullanmaları beklenir (Senemoğlu, 2013). Dil öğrenme stratejilerinin ise iletişimsel yeterlik kazanma amacına yönelik olup, öğrencilerin ikinci dili kavramak ve geliştirmek için genellikle bilinçli olarak kullandıkları belirli davranış veya teknikleri içerdiği ifade edilmektedir (Bekleyen, 2005). Karahan (2007) ilkokul öğrencileri ile yaptığı araştırmasında, öğrencilerin İngilizce öğrenirken en çok kullandığı stratejilerin tamamlayıcı, üst-bilişsel ve duygusal stratejiler, en az kullandığı stratejilerin ise Bilişsel ve Bellek Stratejileri olduğu sonucuna ulaşmıştır. Özmat ve Senemoğlu (2011) araştırmasında hazırlık sınıfı öğrencilerinin dil öğrenirken en çok duyuşsal stratejileri kullandığı en az ise bellek destekleyici stratejileri kullandıkları sonucuna ulaşmıştır. Demirel (2012) araştırmasında, üniversite öğrencilerinin dil öğrenme stratejilerine orta düzeyde sahip oldukları ve yabancı dil öğrenirken en fazla telafi, en az ise bellek stratejilerini kullandıklarını saptanmıştır. Bekleyen (2005)'in araştırma sonuçlarına göre ise İngiliz dili eğitimi bölümüne devam eden öğrencilerin biliş üstü, telafi ve sosyal stratejileri daha fazla kullandığı sonucuna ulaşılmıştır. Ünal, Onursal- Ayırır ve Arıŏlu (2011), araştırmalarında ise İngilizce, Almanca ve Fransızca öğrenen üniversite öğrencilerinin en yüksek düzeyde üst-bilişsel stratejileri kullandığı, en az bellek, bilişsel ve duyuşsal stratejileri kullandıkları sonucuna ulaşmıştır. Araştırma bulguları sonucunda öğrencilere bellek, bilişsel ve duyuşsal stratejilerinin öğretilmesi gerektiği belirtilmiştir.

Öğrencilerin dil öğrenme strateji kullanım düzeyi arttıkça öğrencilerin akademik başarılarının da arttığı sonucuna ulaşılmıştır (Baş, 2014b; Başbay ve Gözüm,2019; Demirel, 2012;Uslan, 2006). Bu bulgu Altan (2003)'ın dil öğrenme stratejileri ile yabancı dil öğrenme başarısı arasındaki ilişkinin doğrusal olması bulgusu ile tutarlıdır. Cesur ve Fer (2011) ise araştırmalarında sadece bellek stratejileri, bilişsel stratejiler, telafi stratejileri ve işitsel öğrenme stilinin yabancı dilde okuma anlama başarısının anlamlı yordayıcıları olduğu sonucuna ulaşmıştır. Öte yandan Çevik ve diğerlerinin (2018) araştırmaları sonucunda, İngilizce dersi başarısı ile kelime öğrenme stratejileri arasında anlamlı bir ilişki tespit edilmemiştir. Tüm bu bulgulara ek olarak Tuncer ve Uluğ (2019) araştırmalarında, yabancı dil alanında öğrenim gören üniversite öğrencilerinin öğrenme stratejileri ile öz-yeterlikleri arasında pozitif bir ilişki olduğu sonucuna da ulaşılmıştır.

\section{Yabancı dil kaygisı}

Yabancı dil kaygısı bireyin anadili dışında bir dili öğrenmesi veya kullanması ile ilişkili endişe, korku gibi duygularını kapsayan bir kavramdır (Tuncer ve Doğan, 2015) ve öğrencilerin dil öğrenme düzeylerini olumsuz (Horwitz, 2001) etkilemektedir. Yabancı dil kaygısı, anadil dışında bir dil

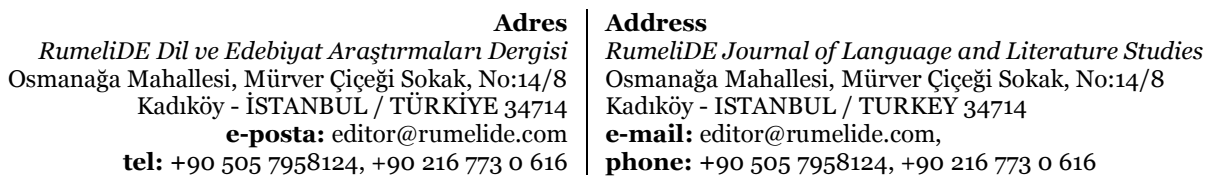


öğrenme sürecinin kendine özgü yapısından kaynaklanan ve bireylerin yabancı dil öğrenmeyle ilgili inançları, duyguları ve davranışlarından oluşan karmaşık bir yapıdır (Horwitz, Horwitz\&Cope, 1986). Sözgelimi, öğrenenlerin yabancı dilde bir ifadenin nasıl telaffuz edileceğini tam anlamıyla öğrenmeden yabancı dilde konuşmak istememeleri bir yabancı dil öğrenme kaygısı olarak sayılabilir (Horwitz, Horwitz\&Cope, 1986). 1983 yılında Texas Üniversitesinde başlangıç seviye yabancı dil öğrencileriyle yürütülen bir araştırmada yapılan görüşmelerde öğrenciler yabancı dil dersleri öncesi kaygıdan donup kalma, sınıfa girmekte çekingen davranma gibi sıkıntılar yaşadıklarını dile getirmişlerdir. Aynı zamanda, öğrenciler kaygıya bağlı konsantrasyon güçlüğü ve unutkanlık gibi sorunlar yaşamışlar ve vücutlarında terleme, bulantı, baş dönmesi gibi kaygı kaynaklı fiziksel belirtiler yaşadıklarını da ifade etmişlerdir (Horwitz, Horwitz\&Cope, 1986). Yabancı dil öğreniminde kaygı odaklı araştırmaların sentezini sunmayı hedefleyen Aydın ve Zengin'in (2008) araştırma sonuçları yabancı dil kaygısının iletişim korkusu, sınav kaygısı ve olumsuz değerlendirilme korkusundan oluştuğunu göstermiştir. Kaygının nedenleri olarak ise dil öğrenenlerin yeterlik düzeyleri, sınav uygulamaları, öğretmen davranışları, yabancı dil derslerinin zorluk düzeyi, dildeki yetenek düzeyi ve kültür olduğu sonucuna ulaşılmıştır. Baş (2014) da araştırmasında yabancı dil öğrenme kaygısına sebep olan faktörlerin; konuşma ve dinleme etkinlikleri, öğretim yöntem ve teknikleri, öğrenenin hata yapma korkusu, öğrenme çevresi, öğretmen tutumları ve sınavlar olduğu sonucuna ulaşmıştır.

Öğrenciler ilk başta dil öğrenmeye, dil öğrenme kaygısı ile başlamazlar. Bu durum sonradan yaşanan olumsuz deneyimlerden veya öğrenilen yabancı dile karşı geliştirilen olumsuz davranış ve düşüncelerden ortaya çıkmaktadır (Maclntyre ve Gardner'dan aktaran Baş, 2014a). Araştırmalar kaygının başarıyı engelleyen anlamlı bir değişken olduğu ve dil öğrenme süreçleri üzerinde etkili olduğunu ortaya koymaktadır. Kaygının aynı zamanda öğrencilerin hatalarının artmasına neden olan bir faktör olduğu da belirtilmektedir (Aydın ve Zengin, 2008). Ortaokul öğrencilerinin yabancı dil öğrenme kaygıları ile İngilizce dersi akademik başarıları arasında negatif orta düzey ilişki olduğu sonucuna ulaşılmıştır (Anyadubalu, 2010).

Doğan'ın (2008) araştırma sonuçları ise ortaöğretim öğrencilerinin yabancı dil kaygı düzeylerinin başarılarını etkilediğini göstermektedir. Pan ve Akay (2015), ise araştırmalarında üniversiteye yeni başlamış öğrencilerin İngilizce dersine karşı olumlu tutuma sahip oldukları ancak kaygı düzeylerinin yüksek olduğu sonucuna ulaşmıştır. Öğrencilerin İngilizce öz yeterlik inançları ve öğrenme kaygıları arasında ise negatif yönde ve anlamlı bir ilişki de bulunmuştur (Anyadubalu, 2010; Oğuz ve Baysal, 2015). Alanyazında ortaokul öğrencilerinin İngilizce dil kaygısı ve öz-yeterlik algısının, İngilizce akademik başarısının önemli yordayıcılarından olduğu sonucuna ulaşan araştırmalar da vardır (Anyadubalu, 2010) .

\section{Sonuç ve öneriler}

Öğrencilerin İngilizce dersi akademik performanslarını birçok faktör etkilemektedir. Bu faktörler, bireysel faktörler ve öğretim ile ilgili faktörler gibi ana başlıklar altında toplanabilir. Bu araştırmada öğrencilerin İngilizce dersi akademik performanslarını etkileyen bireysel faktörler incelenmiştir. Bu kapsamda yabancı dil olarak İngilizce öğrenme başarısını etkileyen ya da İngilizce öğrenmeyi zorlaştıran faktörler olarak motivasyon, öz yeterlik, yabancı dil kaygısı, dil öğrenme stratejileri kullanımı gibi faktörler karşımıza çıkmaktadır. Öğrencilerin başarı beklentilerinin olumsuz inanışlarından etkilendiğini söylemek mümkündür. Öğrencilerin başarısızlıklarını şans ve görevin zorluğu gibi dışsal nedenlere yüklemesi, başarısızlı̆̆ı getirmektedir. Öğrencilerin motivasyonlarını etkileyen en önemli kaynaklardan birisi olarak öğrencilerin başarı ve başarısızlıklarına yaptıkları

\footnotetext{
Adres $\mid$ Address

RumeliDE Dil ve Edebiyat Araşttrmaları Dergisi $\quad$ RumeliDE Journal of Language and Literature Studies Osmanağa Mahallesi, Mürver Çiçeği Sokak, No:14/8 Osmanağa Mahallesi, Mürver Çiçeği Sokak, No:14/8 Kadıköy - İSTANBUL / TÜRKIYE 34714 Kadıköy - ISTANBUL / TURKEY 34714 e-posta: editor@rumelide.com e-mail: editor@rumelide.com, tel: +90 505 7958124, +90 2167730616 phone: +90 505 7958124, +90 2167730616
} 
yüklemeler gösterildiği için, araştırma kapsamında bu konuda yapılan çalışmalar da araştırılmıştır. Aynı zamanda yükleme inançları ile dil öğrenme inanışları arasında ilişki olması da bu konunun araştırımasını önemli kılmıştır. Öğrencilerin başarı/başarısızlığa yaptıkları yüklemelerin motivasyonlarını ve motivasyonlarının da strateji kullanımı üzerine etkisi olduğu düşünülmektedir. Aynı zamanda öğrencilerin başarı/başarısızlı̆ga yaptıkları yüklemeler ilişkin inançları ile öz-yeterlikleri arasında ilişki olduğu belirtilmektedir. Bu noktada öğrencilerin dil öğrenmeye ilişkin inanışlarını olumluya çevirecek öğrenme ortamlarını sağlamak önemlidir. Öğrencilerin motivasyonları da bu durumdan olumlu etkilenecektir. Aynı zamanda öğrencilerin dil öğrenme başarısını John B. Caroll'ın Okulda Öğrenme Modelinde formüle ettiği gibi yetenek ve çaba ürünü haline getirmek de önemlidir. Bu kapsamda öğrenciler şans eseri değil de çabaları sonucunda başarıyı elde ettikleri için, öz-yeterlik algıları da gerçekte olana yaklaşacak ve öğrenciler gerçek başarıya ulaşacaklardır.

Dil öğrenmede, strateji kullanımının da önemi büyüktür. Öğrencilerin strateji kullanımının başarılarını etkilediği düşünüldüğünde, küçük yaşlarda öğrencilere öğrenme stratejilerinin kazandırılması gerekir. Bu noktada öğretme-öğrenme süreçlerinde öğretmenler öğrencilere öğrenme stratejilerinin kullanımı konusunda model olabilirler. Öğrenme stratejilerini etkili kullanan öğrencilerin, diğer öğrencilere strateji kullanımı noktasında model olmalarını sağlayacak öğrenme ortamları da oluşturulabilir. Öğrencilerin strateji kullanımına ilişkin farkındalıklarını arttırmaya yönelik olarak, süreç değerlendirme ve ürün değerlendirmeye birlikte yer verilmesi önemlidir. Çünkü böylece değerlendirme sonuçları üzerine konuşularak, öğrencilerin ders çalışırken izledikleri iyi işleyen yollar ve aksayan yönler ortaya çıkarılabilir.

Dil öğrenme başarısını etkilediği düşünülen bir diğer değişken ise yabancı dil öğrenme kaygısıdır. Öğrencilerin dil öğrenme kaygılarının olumsuz öğrenme yaşantıları sonucunda oluşabileceği düşünülerek, öğrencilere olumlu yaşantı sahibi olacakları ortamların sağlanması önemlidir. Bu noktada öğrencilere küçük yaşlardan itibaren eğlenceli ve başarıyı tadacakları dil öğrenme ortamlarının sunulması, öğrenme ilerlemelerinin anında pekiştirilmesi gerekir. Aynı zamanda dil öğrenme kaygıSı ile öz-yeterlik arasındaki negatif ilişkiyi gösteren araştırmaları da düşünerek, öğrencileri aşırı düzeyde kaygı oluşturacak ortamlardan uzak tutarak, onların başarabileceklerine ilişkin inançlarının oluşmasını sağlayacak öğrenme ortamlarının sağlanması önemlidir.

Sonuç olarak, yabancı dil öğrenme performansını etkilediği düşünülen bireysel faktörlerin incelendiği bu araştırmanın etkili yabancı dil öğretme ve öğrenme ortamlarının oluşturulması hususunda yol gösterici olması beklenmektedir. Çünkü öğrenen özelliklerini dikkate alarak hazırlanan yabancı dil öğrenme ortamları sayesinde hedef dili etkili şekilde kullanan başarılı bireyler yetiştirilmesine de katkı sağlanacağı düşünülmektedir. Araştırmanın aynı zamanda etkili yabancı dil öğrenme ortamlarının düzenlenmesinde hem program geliştiricilere hem de program uygulayıcılarına yol gösterici olması beklenmektedir.

\section{Kaynaklar}

Akpur, U. (2005). Öğrenilmiş Çaresizlik ve Kaygı Düzeylerinin İngilizce Başarı Düzeyine Etkisi (Yayımlanmamış yüksek lisans tezi). Yıldız Teknik Üniversitesi, İstanbul.

Altan, M. Z. (2003). Dil Öğrenme Stratejileri ve Yabancı Dil Başarısı. Eğitim ve Bilim, 28(129).

Altun, S. \& Çolak, E. (2011). Öğrenme Kuramları. Seval Fer (Ed.), Öğrenme Öğretme Kuram ve Yaklaşımları içinde(s. 27-37). Ankara: Anı.

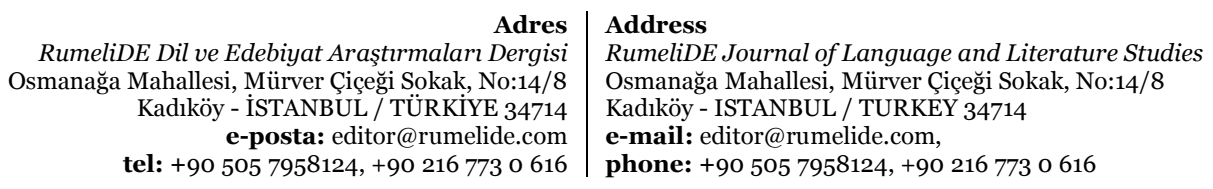

RumeliDE Dil ve Edebiyat Araşttrmaları Dergisi ( tel: +90 505 7958124, +90 2167730616 
Anyadubalu, C. C. (2010). Self-efficacy, anxiety, and performance in the English language among middle-school students in English language program in Satri Si Suriyothai School, Bangkok. International Journal of Human and SocialSciences, 5(3), 193-198.

Atitsogbui, E. N. (2014). Intrinsic and extrinsic motivational factors that influence students' interest in critical languages learning (Order No. 3703371). Erişim Adresi: https://search.proquest.com/dissertations-theses/intrinsic-extrinsic-motivational-factorsthat $/$ docview/1683996254/se-2?accountid=11248

Aydemir, Ö. (2007). İlköğretim II. Kademe Öğrencilerinin İngilizce Dersinde Kullandıkları Başarı Başarısızhk Yüklemeleri (Yayımlanmamış yüksek lisans tezi). Trakya Üniversitesi, Edirne.

Aydın, S. ve Zengin, B. (2008). Yabancı dil öğreniminde kaygı: Bir literatür özeti. Dil ve Dilbilimi Çalışmaları Dergisi, 4(1).

Bandura, A. (1977), Self-efficacy: toward a unifying theory of behavioral change. Psychological Review, 84, 191-215.

Baran, G.,ve Halıcı, P. (2006). Çocuklarda Yabancı Dil Eğitimi. Eurasian Journal of Educational Research (EJER), 24,44-52.

Baş, G. (2014a). Lise Öğrencilerinde Yabancı Dil Öğrenme Kaygısı: Nitel bir araştırma. Pamukkale Üniversitesi Ĕ̆itim Fakültesi Dergisi, 36(2), 101-119.

Baş, G. (2014b). Lise Öğrencilerinin Dil Öğrenme Stratejileri İle İngilizce Dersindeki Akademik Başarıları Arasındaki İlişki. Dokuz Eylül Üniversitesi Buca Eğitim Fakültesi Dergisi, (37), 166180 .

Başbay, A., ve Gözüm, E. (2019). Dil Öğrenme Stratejilerine Göre İngilizce Öz Yeterlik İnancı ve İngilizce Akademik Başarıları. Dil Eğitimi ve Araşttrmaları Dergisi, 5(1), 12-29.

Bekleyen, N. (2005). Öğretmen Adayları Tarafından Kullanılan Dil Öğrenme Stratejileri. Çukurova Üniversitesi Sosyal Bilimler Enstitüsü Dergisi, 14(2), 113-122.

Besimoğlu, S., Serdar, H., \& Yavuz, Ş. (2010). Exploring students' attributions for their successes and failures in English language learning. Hasan Ali Yücel Eğitim Fakültesi Dergisi, 14(2), 75-89.

Bialystok, E. (1978). A theoretical model of second language learning. Language Learning, 28 (1), 6983.

Bloom, B.S. (2012). İnsan nitelikleri ve okulda öğrenme. (D. A. Özçelik, Çev.) Ankara: Pegem.

Cesur, M. O., ve Seval, F. E. R. (2011). Öğrenme stratejileri, stilleri ve yabancı dilde okuma-anlama başarısı arasındaki ilişkiler örüntüsü. Hacettepe Üniversitesi Eğitim Fakültesi Dergisi, 41(41).

Çevik, H.,Orakcı, Ş., Aktan, O., Toraman, Ç., ve Ayçiçek, B. (2018). Ortaokul Öğrencilerinin Kelime Öğrenme Stratejilerinin Çeşitli Değişkenler Bakımından İncelenmesi (Ankara İli Örneği). Abant İzzet Baysal Üniversitesi Eğitim Fakültesi Dergisi, 18(2), 796-814.

Chen, Y. (2020). Correlation between Self-Efficacy and English Performance. International Journal of Emerging Technologies in Learning, 15(8), 223-234.

Çimen, S. (2011). Eğitim Fakültesi Öğrencilerinin İngilizceye Yönelik Tutum, İngilizce Kaygısı ve Öz yeterlik Düzeylerinin İncelenmesi (Yayımlanmamış yüksek lisans tezi) .Zonguldak Karaelmas Üniversitesi, Zonguldak.

Demirel, M. (2012). Üniversite Öğrencilerinin Kullandıkları Dil Öğrenme Stratejileri. Hacettepe Üniversitesi Eğitim Fakültesi Dergisi, 43, 141-153.

Demirel, Ö. (2020). Yabancı Dil Öğretimi. Ankara: Pegem.

Doğan, A. (2008).Lise Öğrencilerinin İngilizce Öğrenimlerini Etkileyen Yabancı Dil Kaygısı. Dil Dergisi, (139), 48-67.

Erden, M ve Akman, Y. (2014). Eğitim psikolojisi: Gelişim-öğrenme-öğretme. Ankara: Arkadaş.

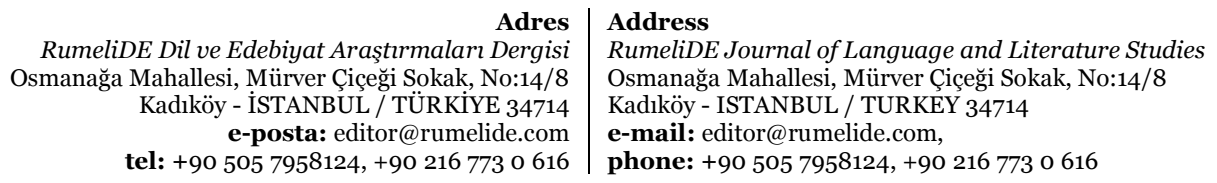


Genç, G.,Kuluşaklı, E., \& Aydın, S. (2016). Exploring EFL learners' perceived self-efficacyandbeliefs on English languagelearning. AustralianJournal of TeacherEducation, 41(2), 4.

Gömleksiz, M.,\&Kılınç, H. (2014). Lise 12. Sınıf öğrencilerinin İngilizce öz yeterlik inançlarina ilişkin görüssleri. Firat Üniversitesi Sosyal Bilimler Dergisi, 24(2), 43-6o.

Güloğlu, B. (2015). Öğrenilmiş İyimserlik. Bengü Ergüner Tekinalp ve Şerife Işık Terzi (Ed.), Eğitimde Pozitif Psikoloji Uygulamaları içinde (s.191-218). Ankara: Pegem Akademi.

Horwitz, E.K.,Horwitz, M. B. veCope, J. (1986). Foreign Language Classroom Anxiety. The Modern Language Journal, 70(2), 125-132.

Horwitz, E.K.(2001). Language Anxiety And Achievement .Annual Review of Applied Linguistics, 21, 112-126.

Karahan, V. (2007). Devlet İlköğretim Okulu Birinci Kademe Dördüncü Sinff Öğrencilerinin İngilizce Öğrenirken Kullandıkları Öğrenme Stratejileri (Yayımlanmamış Yüksek Lisans Tezi).Yıldız Teknik Üniversitesi, İstanbul.

Kitikanan, P.,veSasimonton, P. (2017). The Relationship between English Self-Efficacy and English Learning Achievement of L2 Thai Learners. Learn Journal: Language Educationand Acquisition Research Network, 10(1), 149-164.

Li, M. (2016). Contributory factors to language learning as perceived by university-level chinese heritage language learners in the united states (Order No. 10297045). Available from ProQuestDissertations\&Theses Global. (1847568626). Erişim Adresi: https://search.proquest.com/dissertations-theses/contributory-factors-language-learningas/docview/1847568626/se-2?accountid=11248

Mahyuddin, R.,Elias, H., Cheong, L. S., Muhamad, M. F., Noordin, N., \& Abdullah, M. C. (2006). The relationship between students' self efficacy and their English language achievement. Malaysian Journal of Educators and Education, 21, 61-71.

Memduhoğlu, H. B.,ve Çelik, Ş. N. (2015). İngilizce öğretmen adayı olan ve ingilizce öğretmeni olmayı planlayan üniversite öğrencilerinin ingilizce öz yeterlik algıları. İnönü Üniversitesi Ĕ̆itim Fakültesi Dergisi. 16 (2), 17-32.

Nolen-Hoeksema, S.,Girgus, J. S., \&Seligman, M. E. (1986). Learned helplessness in children: A longitudinal study of depression, achievement, and explanatory style. Journal of Personality and Social Psychology, 51(2), 435-442. Erişim Adresi: https://doi.org/10.1037/oo223514.51.2.435.

Oğuz, A., Baysal E. A. (2015). Ortaöğretim Öğrencilerinin İngilizce Öğrenme Kaygıları ve İngilizce Öz yeterlik İnançlarının İncelenmesi. Ĕ̆itim ve Öğretim Araştırmaları Dergisi, 4(3), 107-117.

Özçelik, D.A.(2013). Okullarda Ölçme ve Değerlendirme Öğretmen El Kitabı. Ankara: Pegem.

Özmat, D. (2017). İngilizce Öğrenmeyi Zorlaştıran Faktörler (Yayımlanmamış Doktora Tezi). Hacettepe Üniversitesi, Ankara.

Özmat, D ve Senemoğlu, N . (2011). İngilizce Hazırlık Okulu Öğretim Görevlilerinin ve Öğrencilerinin Dil Öğrenme Stratejilerinin Kullanımına ve Öğretimine İlişkin Görüşleri .Milli Eğitim Dergisi . DOI: $10.37669 /$ milliegitim.709347.

Pan, V. L. ve Akay, C. (2015). Eğitim Fakültesinde Yabancı Dil Dersi Alan Öğrencilerin Yabancı Dil Dersine Yönelik Tutumlarının ve Sınıf Kaygılarının İncelenmesi. Elektronik Sosyal Bilimler Dergisi, 14(55), 79-97.

Perez, M. (1995). Factors affecting english as a second language learning for new and returning international college students enrolled at an english language institute in the united states (Order No. 9534411).

Ritchie, William F. (1999). An Exploration of College Student Explanatory Style and Its Relationship to Academic Performance (Unpublished Doctoral Dissertation). Cornell University, New York.

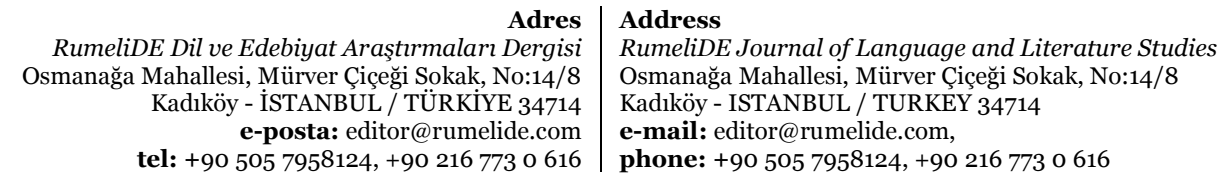


Raoofi, S., Tan, BeeHoon.,Chan, SweeHeng (2012). Self-Efficacy in Second/Foreign Language Learning Contexts. English Language Teaching, v5 n11 p60-73 2012

Seligman, M. E. P.(2007). Öğrenilmiş İyimserlik(Çev. S. Kunt Akbaş). Ankara: HYB.

Semiz, Ö. (2011). Bir Eğitim Programının Yükleme İnançları, Öz-yeterlik, Dil Öğrenme İnanışları, Başarı ve Öğrenci Çabası Üzerindeki Etkileri: Motivasyon Yönünden Risk Altındaki Yabancı Dil Öğrencileri Üzerine Bir Çalışma (Yayınlanmamış Doktora Tezi). Atatürk Üniversitesi.

Senemoğlu,N. (2013).Gelişim Öğrenme ve Öğretim. Ankara: Pegem Akademi.

Shih, Huei-Ju (2019). L2 Anxiety, Self-Regulatory Strategies, Self-Efficacy, Intended Effort and Academic Achievement: A Structural Equation Modeling Approach. International Education Studies, 12 (3), 24-35.

Şad, S. N.(2011). İlköğretim Birinci kademe İngilizce Öğretim Programını Çocuklara Yabancı Dil Öğretiminin Duyuşsal Hedeflerini Gerçekleştirme Düzeyi (Yayımlanmamış doktora tezi). İnönü Üniversitesi, Malatya.

Taşkıran, A.,ve Aydın, B. D. P. (2017). İngilizce'yi Yabancı Dil Olarak Öğrenenlerin Başarı ve Başarısızlıklarına Yaptıkları Nedensel Yüklemeler ve Boyutları. Anadolu Üniversitesi Sosyal Bilimler Dergisi.17 (2), 11-26.

Tuncer, M. ve Doğan, Y. (2015). Hazırlık sınıfı öğrencilerinin Yabancı Dil Ders Kaygıları ve Akademik Öz yeterlikleri Arasındaki İlişki. Dil ve Edebiyat Eğitimi Dergisi, 14, 153-167.

Tuncer, M, Uluğ, H. (2019). Yabancı dil öğrenim stratejileri ile öz yeterlik algıları arasındaki ilişkilerin incelenmesi .International Journal of Social Sciences and Education Research, 5 (4) , 447-463 . DOI: $10.24289 /$ ijsser.642305

Uslan, E. U. (2006). Öğrenme stratejileri kullanımının İngilizce dilbilgisi başarısı üzerindeki etkiliği (Doktora Tezi), DEÜ Eğitim Bilimleri Enstitüsü.

Ünal, Ç. D., Onursal Ayırır, İ. ve Arıoğlu, S. (2011). İngilizce, Almanca ve Fransızca Öğgenen Üniversite Öğrencilerinde Yabancı Dil Öğrenme Stratejilerinin Kullanımı. Hacettepe Üniversitesi Ë̆itim Fakültesi Dergisi, 41(41).

Weda, S., Abdul Samad, I., Patak, A. A. ve Fitriani, S. S.(2018). 140 The Effects of Self-Efficacy Belief, Motivation, and Learning Strategies on Students' AcademicPerformance in English in Higher Education. The Asian EFL Journal Quarterly, 20 (9.2). pp. 140-168. ISSN 1738-1460.

Weiner, B. (1986). An Attributional Theory of Motivation and Emotion. California: Springer-Verlag

Zimmerman, B. J. (2002). Becoming a self-regulated learner: an overview. Theory Into Practice, 41(2), 64- 70, from Academic Search Premier Database. 